\title{
An Essay on Reading the Change of Cultural Heritage Components Through Semantic Literature: Historical Mesires in Istanbul
}

\author{
Kültürel Miras Ögelerinin Değişimini Anlambilim Yazını Aracılığıyla Okumak Üzerine \\ Bir Deneme: İstanbul'daki Tarihi Mesire Alanları Örneği
}

Töre SEÇilLMişLER, Mehmet Doruk ÖZÜGÜL, Bora YERLiYURT

\section{ABSTRACT}

Since their first settlement historical cities have been changing due to both natural and social conditions. These changes also have reflections on cities' physical structures where they could be entirely traced. There are plenty conserved, changed and lost physical components in the old Ottoman capital Istanbul in time. It is known that several spatial elements, such as the residential buildings, public buildings, were either collapsed or lost. Mesires are also within these lost elements which represent information on Istanbul's recreation culture and green areas in the Ottoman Era. Thus, the aim of this study is to evaluate the change of mesire areas and recreation culture of Ottoman culture. Ottoman period, changes in Mesires are exemplified relating to some significant milestones and classified. In methodological terms, changes in Mesires are read within a semiological perspective considering denotative and connotative changes. Consequently, it is emphasized that Mesire culture and areas, which are inherited from Ottomans to today's Istanbul society, have changed and/or lost.

\section{ÖZET}

Tarihi kentler kuruldukları günden itibaren, doğal ve sosyal koşullar çerçevesinde değişerek, günümüze ulaşmıştır. Bu değişimler kentlerin fiziki yapısına yansımış olup, bu izler bütününde kentlerin geçirdikleri evreler okunabilmektedir. Osmanlı imparatorluğu'nun başkenti olan Istanbul'da geçmişten günümüze korunmuş, değişerek ulaşmış veya yitirilmiş birçok fizik mekân ögesi bulunmaktadır. Konut yapıları, kamu yapıları vb. çok sayıda fizik mekân ögesinin yıkıldığı ya da yitirildiği bilinmektedir. Yitirilen fizik mekân ögeleri içerisinde istanbul'da Osmanlı döneminde rekreasyon kültürü ve yeşil alan kullanımına ilişkin bilgi sunan mesire/çayır alanları da bulunmaktadır. Buradan hareketle çalışmanın amacı Osmanlı kültüründe önemli yer tutan mesire alanlarının ve kültürünün değişimini irdelemektir. Osmanlı'dan günümüze yaşanan toplumsal kırılma noktaları ile mesirelerdeki değişim örneklerle anlatılmıştır. Yöntemsel açıdan bu mesire alanlarında yaşanan değişim anlambilim yazınındaki birincil ve ikincil işlev değişimleri ışığında anlamlandırılmıştır. Sonuç olarak günümüz İstanbul'una Osmanlı'dan miras kalan mesire kültürünün ve alanlarının değişime uğradığı ve/veya yitirilmesi ile karşı karşıya kalındığı sonucuna ulaşılmıştır. 


\section{Introduction}

Cities are settlements that are transformed by natural and manmade causes in which physical space is created on a daily basis. Throughout the process of reproducing space (tangible and intangible) elements of cultural heritage, which are proof of former periods, can be preserved in some cases and in some aspects, while not in others. This is mainly due to the changing demands of the past and present. One of the problems associated with the failure to preserve cultural heritage is the creation of voids in collective memory.

The framework of efforts aimed at preserving cultural heritage is trying to be defined with legal and administrative legislation that also includes the discipline of planning, while various sanctions are employed to succeed in preservation itself. However, in some cases, elements of cultural heritage cannot be preserved regardless of such efforts. The aim of this study is to attempt at interpret the problematique of the failure to preserve elements of cultural heritage based on scientific literature. This study will be executed through mesire (recreational areas), which are elements of cultural heritage in the physical space, inherited from the Ottomans. This is a topic that has rarely been studied in Turkey. Mesires (recreational areas) often contain man-made elements like pavilions (summer palaces), courts, tombs, namazgahs (outdoor altars), bridges and stables. This study focuses on the example of Istanbul to incorporate periods of intense social and cultural change like Westernisation and the Republican Era. A process analysis has been performed with the help of the conceptualisations of primary function and secondary function that is mentioned in semiology literature in order to explain changes taking place in the mesires (recreational areas) of Istanbul on the basis of examined examples.

\section{Conceptual Framework}

Culture has more than one definition. As a result of the meanings ascribed to it Bozkurt Güvenç (2005) describes culture as the sum of all its different meanings. ${ }^{1}$ Marx defines culture as everything created by mankind in response to that created by nature and in doing so uses a general statement concerning the concept of culture. Accordingly, elements of physical space like structures, green spaces etc. created and inhabited by societies are categorised as elements of tangible space while various symbol systems and social codes like language, religion, writing are regarded as intangible cultural values. This is the essence of cultural/collective memory, which is one of the most important aspects that enable social togetherness.

1 Güvenç, 2005.

Generally speaking, memory is mostly addressed as a topic that is arguably created in scope of a person's physiological characteristics. However it is possible to establish a relation between memory and the physiological characteristics of a person in scope of wellbeing and quantitative capacity. Having said that, society is the main factor in the creation of human memory. Individuals recall memories, even those regarded as special, within the frame of communication or interaction with individuals and/or groups that make up society itself. ${ }^{2}$

Memory has four different external dimensions. The first is mimetic memory and is about imitating behaviour. The second is material memory and is a matter of chronology, which recollects different pasts while living in the present inside the world experienced by the individual. The third is communicative memory that is based on language and communication. The fourth is cultural memory and is about transferring meaning. Cultural memory is the domain in which the former three categorisations converge in coherence. ${ }^{3}$

Humans acquire new experiences, knowledge and symbolic values, which society accepts and shares. Humans need a tool to store these acquisitions in order to use them when necessary in the future. This is called memory. A person uses the required information by recalling it from his/her memory. ${ }^{4}$

In order to create an experience in his or her memory an individual needs to associate this with at least one of the following: a person, a place or an incident. This is known as a symbol of recollection. The individual utilises the three basic characteristics of these symbols of recollection in establishing such a relation. These are loyalty to time and space, loyalty to a group and the ability to re-establish, which is a process in its own. ${ }^{5}$ Based on these characteristics, individuals prolong symbols of recollection in existing physical spaces or reveal assets from the past that are underground to preserve or construct cultural memory and cultural identity, and to establish a connection between elements of physical space from the past that are regarded as cultural heritage. Thereby it could be argued that a link is established between members of a society/group.

Material and non-material values that constitute parts of the cultural system that create cultural identity become lasting as they are passed down from generation to generation. For the generation that is at the end of this process, all inherited assets are defined as cultural heritage. $^{6}$

2 Assmann, 2001.

Assmann, 2001.
4 Assmann, 2001.
5 Assmann, 2001.
Howard, 2003.

Güvenç, 2005. 
Culture changes. This happens when individuals' physical and/or psychological needs can no longer be met by the current culture. New principles and new institutions emerge within society. ${ }^{7}$ Cultural heritage may also change from generation to generation. Some may get lost while other are added. This may occur in line with the dominant powers/values within a changing society. In this context, heritage could be expressed as history within the framework of a specific objective, policy or etc. ${ }^{8}$

In some cases, cultural heritage may be lost completely when all data related to cultural systems is erased from individuals' memories. Consequently this could yield a society that has lost its identity, and unable to relate to its past. In some cases there are attempts to construct an identity by creating a past, a heritage that existing individuals can connect with. Examples would include the French Revolution and the Industrial Revolution in which each nation sought a motherland and a past at the point where social disarrangement was resolved with societies transforming into nations. ${ }^{9}$ Consequently, societies prolong symbols of recollection in existing physical spaces or reveal assets from the past that are underground to preserve or construct cultural memory and cultural identity, and to establish a connection between elements of physical space from the past that are regarded as cultural heritage. This establishes a connection between the individuals of a society or group. It could be said that it is important to sustain elements of cultural heritage in order to preserve this connection.

Typologically speaking, the notion of value in abstract and tangible cultural heritage is divided into two: socio-cultural and economic. Socio-cultural assets are of "non-use value". Features like symbolic value / semantic/semiologic value, historic value, cultural/symbolic value, social value, belief value, aesthetic value etc. all define the universe of socio-cultural values. Whereas economic values include "use value" and tangible values that have market value. In this context it is argued that preserving and sustaining abstract and tangible cultural heritage from the past depends on establishing a meaningful and/or functional connection with the current social and/or cultural structure. Effectively, the mentioned elements of cultural heritage may not be protected even if measures are taken with legal legislation. ${ }^{10,11,12}$

Today, the analysis of the problem about the trans-

\footnotetext{
8 Preucel ve Meskell, 9 Kaya, 2004.

2004.

${ }^{10}$ Mason, 2002.
}

formation of cultural heritage is generally carried out based on quantitative data. However the issue of interfering with the structure/space is mostly subjective with the exception of preservation principles. Because, in fact, the extent an element of heritage is protected makes it all the more difficult to answer the question of accepting the sustainability of cultural heritage itself. Having said that, interpreting/examining changes to the element of cultural heritage in context of symbol/ meaning and use value within the concept of culture might contribute to finding an answer to the question.

\section{The Method of Interpreting Change:}

\section{A Selection from Semantic Literature}

Undoubtedly, semantic literature has been used to offer various explanations in many different areas from linguistics to sociology, architecture to urban planning. This study does not aim to discuss semantic literature in detail. Instead, it has chosen to use conceptualisations in such literature that are particularly suitable to analyse changes taking place in urban spaces as a procedural framework aimed at the objective.

Interpreted at the general level, physical space is used by people within the framework of two different constructs of relevance. The first is denotation/signifier and the second is connotation/signified, which expresses symbolic/semantic value. The term denotation/signifier refers to the use of a space or object within communicative capacity; the function it has at a definitive and traditional level. Whereas the term connotation/signified is the expansion of the concept of function of a space or an object within society, in context of use in the symbolic capacity. This is no less used than functional capacity. ${ }^{13}$

Convinced that the concepts of denotation/signifier and connotation/signified caused confusion in discussions, Eco preferred to describe these phenomena using the terms primary function and secondary function. According to Eco, this distinction is not a classification based on criteria, it is rather a terminology explained to simplify communication with the reader. Having said that, Eco also pointed out that there is no order of priority between the two functions. ${ }^{14}$ Eco also emphasised that connotation/signified, which was regarded as a secondary function may, in some cases, have the ability of becoming a primary function. ${ }^{15}$

Social change results in the adoption of new institutions and principles. In context of cities this materialises in the form of an urban element losing its primary and/or secondary function, regaining its function after

${ }^{13}$ Eco, $1980 . \quad{ }^{14}$ Eco, $1980 . \quad{ }^{15}$ Eco, 1980. 
having lost it or being used for other functions. Eco describes this phenomenon as codes of enrichment. ${ }^{16}$

Umberto Eco explains the different probabilities within primary and secondary function systematics as follows:

i. If an architectural/urban object/space has lost its primary function but can maintain its secondary function, that physical structure may survive. For instance, although the Parthenon has lost its function as a place of worship, it is nonetheless preserved as it establishes a philological relation with Greek thought. At this point, it could be said that the structure that is considered to be a tangible element of cultural heritage has been preserved since it has established a link with its secondary function.

ii. The physical structure may be sustained if the primary function continues, even if the secondary function has been lost. Several structures (like ones created by former cultures) that have blurred/lost dimensions of meaning parallel to different users after the initial builder and are examples of tangible cultural heritage can be regarded as an example to this situation.

iii. An object may be preserved even if primary and secondary functions have been lost and the original secondary function has been replaced with a new one. This phenomenon is coined the codes of enrichment. Eco explains this with the pyramid example. The indicant, or in other words, the primary function of the pyramids is a tomb. Today they have lost this function. The indicant of the pyramids have been lost due to a failure in accurately passing on the astrological and geometrical symbol values in ancient Egypt with their depth of meaning. Whereas today the pyramids are still preserved because the indicant which is the secondary function has undergone code enrichment with a new function in context of tourism. From this perspective, it could be argued that it is possible to preserve tangible elements of cultural heritage.

iv. An object may be preserved even if primary and secondary functions have been lost and replaced with original primary function values. A good example would be the French Street (formerly Rue d'Alger) in Istanbul, which has undergone a transformation of primary functions due to fashion trends while losing its secondary function in

\footnotetext{
${ }^{16}$ Eco, 1980
}

earlier periods.

v. Urban elements may not be preserved if both functions have been lost. In terms of modern preservation practices, the condition an element is preserved is also linked with institutional organisations related to preservation.

vi. An urban element may be sustained if primary and secondary functions continue to exist. ${ }^{17}$

\section{The Concept of Mesire (Recreation Areas) as an Element of Cultural Heritage}

The built environment occupies an important place within tangible elements of cultural heritage. Within the built environment, man-made/natural landscapes like recreational areas, which contain pavilions (summer palaces), courts, tombs, namazgahs (outdoor altars), bridges and stables are considered as tangible elements of cultural heritage in terms of understanding social life in previous civilisations and guarantee their sustainability by establishing a link with existing society within the framework of facts like understanding how former cultures behaved towards nature, identify their recreation culture, follow how and why they changed etc. Having said that, the recreation culture of the period, and its reference to religious, social and political structures emerge as intangible elements of cultural heritage.

The Unabridged Turkish Dictionary published by the Turkish Language Association defines mesire (recreational area) as "a place to wander and explore". ${ }^{18}$ However Evliya Chalabi's commentaries on mesires suggest that these places were used for other purposes as well. ${ }^{19}$ It is understood that mesires were also an attraction for groups who would organise events and visit religious places. Artisan guilds would arrange outings to meadows and mesires. On some occasions groups would camp for 7 to 10 days, and these stay-overs would include entertainment like saz (music), çengi (female dancers), köçek (male dancers), ortaoyunu (theatre), gölge oyunu (shadow play) and acrobatics; horses would be grazed, feasts would be given at the start and end of the season. Sometimes the sultan would set-up tents for the public and mesires by the sea, rivers or lakes would allow people to travel on caiques (row boats). ${ }^{20}$

Therefore, there is a need to perceive the concept

\footnotetext{
${ }^{17}$ Eco, 1980.

${ }^{18} \mathrm{http}: / / \mathrm{ww} w . \mathrm{tdk}$.gov.tr/index.php? option=com bts\&arama=kelime\&guid=TTD.GTS.545885f2a1c5e9.54526917 [Access Date: 03.04.2014].

${ }^{19}$ Eldem, 1977.

${ }^{20}$ Aktaş, 2011.
} 
of mesire as a formation process or the whole of the events taking place at these locations. That is why emphasising the unique characteristics of the location to be used for recreational purposes and also emphasising the aspects of being involved in recreational activities (groups of people enjoying the scenery, wandering, feasts, communion and entertainment with music, sportive activities, ceremonies, worshiping and other such activities) with implemented arrangements contribute to the accurate conceptualisation of the mesire concept. $^{21}$

The interest towards mesires has changed in different periods throughout history. Changing conditions; social, cultural, political and economic values have transformed mesire places and the relation and interaction of user predisposition towards open spaces like mesires. $^{22}$

\section{The Background of Change in Istanbul's Mesires from the Westernisation Period Until Today}

Istanbul is a multi-layered city in which mesire places could be regarded as tangible elements of cultural heritage in scope of the built environment. These places offer insight into the recreation culture of social life in the city during the Ottoman Period. However, it could be said that mesire places, which are open to public use, have changed and lost their authenticity like other elements of the built environment (structures like aqueducts, city walls, residences etc.)

The process of Westernisation, which started during the Ottoman Empire in the $18^{\text {th }}$ century, still continues. Two basic breaking points have been experienced in this context. The first one is social change and the second is the change in state structure. We encounter two scales in connection with this. The first is the scale of Istanbul and the other is the scale of the entire state.

Mesire places gradually started to lose their appeal parallel to the social changes taking place throughout the Ottoman Empire. During this period known as the Westernisation Process society, particularly the socioeconomically affluent, gradually Europeanised and adopted a different life-style which led to a part of the society distancing themselves to mesire places. Recreation culture changed for this part of society who now preferred to go to shops, coffee houses, theatres, patisseries and entertainment clubs opening in the Beyoğlu (Pera) district rather than mesire places. In the meanwhile, in an effort to westernise state appa- ratus started to allocate green spaces under the name Municipal Parks. Consequently, a series of spaces maintained by the municipality started to appear. The first of these was the public park in Büyük Çamlıca in Anatolian Istanbul during the reign of Abdülâziz. At the end of the 19th century other gardens including Sultan Ahmed Municipal Garden, Tepebaşı Municipal Garden, Taksim Municipal Garden, Bakırköy Municipal Garden, Tophanelioğlu Municipal Garden were also opened to

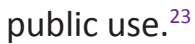

Another issue that affects mesire places in the upper scale is related to the organisation of the modernist city. The basic principal of the modern mentality that reflects on to the city is isolating and separating function fields from each other. Considering this change in relation to mesire places it is possible to say that theatre and opera halls replaced performances like orta oyunu (theatre) that were traditionally staged in mesire places. Another function attributed to mesire places was strolling and relaxing but the new municipal parks opening in different parts of the city gradually started to meet this need. Similarly entertainment activities were relocated from mesires to the ballrooms in the Pera district. In other words, in scope of the perception gaining popularity from the beginning of the $20^{\text {th }}$ century these events that were traditionally organised collectively within mesire places were relocated to indoor/outdoor spaces designed for different functions in different parts of the city in conjunction with changes taking place in society.

Changes to the regime during the transition from the Ottoman Empire to the Republic of Turkey led to fundamental transformations, particularly in Istanbul. Most importantly, after the proclamation of the republic, Istanbul was left to the rule of a local government after having been the capital of an empire for so long. This resulted in a status change in several indoor and outdoor spaces that belonged to the dynasty like palaces and stables etc.

Another breaking point related to Mesire places is the socio-economic changes taking place in Turkey during the 1950s. The amount of mesire places in Istanbul dwindled due to a number of reasons including illegal housing, the construction of industrial facilities and harbours due to domestic migration and the associated changes taking place in Istanbul's infrastructure (opening new transport routes etc.). Starting from the 1950s, Istanbul's most important mesire places were lost due to population density and development, while

\footnotetext{
${ }^{23}$ Evyapan, 1972.
}

${ }^{21}$ Cerasi, 2001. $\quad{ }^{22}$ Gürbüz, 2009. 
small portions of a few mesire places survived in the form of parks. ${ }^{24,25,26,27}$

\section{Associating Istanbul's Mesire Places with the Systematics of Changes in Primary and Secondary Functions}

Today legal and administrative institutions like state apparatus, protection committees, laws etc. try to take measures to preserve urban elements or, on the contrary, act as a facilitator to prevent urban elements being preserved. What is emphasised in scope of the approach Eco tried to explain in six articles is the response users living in the city give towards preserving urban elements. From this point of view, the issue could be analysed based on the examples below by evaluating unpreserved or preserved mesires in scope of Eco's approach and establishing a link with the primary and secondary function change systematics. ${ }^{28}$

\footnotetext{
${ }^{24}$ Evyapan, $1972 . \quad 25$ Eldem, 1977.
}

${ }^{26}$ According to Gürbüz (2009) the number of mesire places in Istanbul is unclear. This is mainly because literature about mesire places are mostly documents that contain subjective comments written by travellers. Thus, different texts refer to different mesire places. Based on this, the names of main mesire places in Ottoman Istanbul are as follows: Prince's Islands: Çamlıklar and hill in Büyükada, Çam Limanı in Heybeliada. Üsküdar and Kadıköy region: Kuşdili Meadow, Yoğurtçu Meadow, Fener Garden, Kalamış, Haydarpaşa Meadow in Kadıköy Ciftehavuzlar, Mama (towards Merdivenköy in Göztepe) in Erenköy; Su menbası (spring) in Kayışdağı; Orman in Alemdağı; Büyük Çamlıca Hill, Küçük Çamlıca Hill, Libadiye in Çamlıca; Şemsipaşa Pavillion place, İbrahim Ağa Meadow, Susuz Bağı, Alay Köşkü place, Duvardibi in Üsküdar. Anatolian Side of the Bosphorus: Havuzbaşı in Beylerbeyi; Top mahalli (Cannon post) in Vaniköyü; Göksu and Küçüksu Meadows in Anadoluhisarı; Kavacık on Anadoluhisarı hill; Hekimbaşı Farm behind Anadoluhisarı; Paşabahçesi, Sultaniye Meadow, Çubuklu Meadow around Kanlıca; Mihrabad on Kanlıca hill, Göztepe spring behind Kanlıca; Meshur Meadow, Karakulak spring in Beykoz, Yuşa Hill on Beykoz Hill, Tokad Pavillion Meadow, Anadolu Lighthouse around Beykoz. European Side of the Bosphorus: Firıldak Garden, Hünkar, Cırçır, Fındık, Kestane, Otuzbir spring sties in Sarıyer; Kalender near Tarabya, Çayır in Tarabya; Koru in Mirgün (Emirgan); Fıstıklı in Boyacıköyü; Baltalimanı Meadow in Rumelihisarı, Şehitlik Hill on Rumelihisarı Hill; Pavillion place in Bebek; Ihlamur in Beşiktaş; Zincirlikuyu behind Beşiktaş. İstanbul (Historic Peninsula - Fatih) and environs: Kağıthane Mesire, Silahtarağa Fountain in Kağıthane; Ayine Kavak (Aynalıkavak) Pavillion place in Kasımpaşa; Ok Meydanı above Kasımpaşa; Fulya Garden, Türbe Garden, Bahariye Pavilion place in Eyüp; Söğütlüçeşme, Sakızağacı, Siyavuş Paşa Farm, Veli Efendi Meadow, Bayram Paşa Meadow around Makriköy (Bakırköy); Florya in Ayastafanos (Yeşilköy). Some of the mesire places mentioned in this study have been included in scope of examples.

${ }^{27}$ According to Seçilmişler, Özügül and Yerliyurt (2014) some mesire places that have been downsized or lost entirely due to social and legal processes have been collated based on developing the examples set forth by Eldem and Aktaş.

${ }^{28}$ Mesires are places used for recreational purposes and contain temporary (tents for short stays, mobile stages for performances) and permanent structures developed for functions like accommodation, worship and entertainment. In scope of Eco's primary and secondary function systematics, the primary function or denotation/signifier is recreation. Whereas the secondary function or connotation/ signified could be interpreted as periodical uses carried out in these places which register in urban memory (jewellers using specific mesire places during specific times, grazing imperial horses), abstract meanings ascribed to mesires (those visited based on the public belief that tombs and healing waters exist) and privately used mesires pointing out to the political and social structure of the period. The method elaborated in scope of the study is based on a hermeneutic approach. However the aim here is to offer a different approach to the problematique of preserving cultural heritage, not to have a methodological discussion. i. Mesires that have lost their primary and secondary functions: Their existence only depends on legislative arrangements. In other words, mesires would not exist should there be no constraint based on legislative arrangements. Uzunçayır mesire place could be given as an example to this.

ii. Mesires that have lost their primary function, but maintain their secondary function: Although the area situated on Yuşa Hill no longer has a recreational function it could be said it has still been preserved due people visiting the tomb of St. Yuşa, and to the presence of places of Islamic worship within the mentioned area.

iii. Mesires that have maintained their primary function but lost their secondary function: This defines mesire places that maintain their recreational function but have lost their connotation. Mesire places open for private use could be given as an example. Ihlamur Mesire belongs to the palace and was occasionally occupied by the sultan but especially used to host his foreign guests. It refers to the fact that besides the recreational function, the mesire is not considered public space in terms of connotation. Today, although it is used for recreational purposes, it is nonetheless open to public use.

iv. Mesires that have lost their primary and secondary functions but undergone codes of enrichment in their secondary function: Today some mesires have lost recreational functions like sports and overnight staying however become used for touristic purposes. The mesire place inside Beylerbeyi Palace can be given as an example. The mentioned area, which includes part of the Istavroz (Crucifix) Meadow, is no longer used for recreational purposes and also has lost its property of being an urban space that belongs to the sultan. However, because it is used for touristic purposes today, it could be said that it is partially preserved to a certain extent by undergoing codes of enrichment in its secondary function as explained in Eco's pyramid example.

$v$. Mesires that have lost their primary and secondary functions but undergone codes of enrichment in their primary function: It could be said that a change has taken place in the second function of the mesire that has lost its primary function as a recreational area and also referred to as the Istavroz (crucifix) Meadow in urban memory, in effect making a reference to a specific social structure. A part of the mentioned area has been 
allocated for military use, so it could be said it is partially preserved even though it is used for different purposes after having undergone codes of enrichment in its primary function.

vi. Mesires that have preserved/sustained their pri- mary and secondary functions: There is no example of this in Istanbul because there isn't a single mesire that has been preserved entirely.

\section{Conclusion}

From the past to the present mesire places in Istan-

Table 1. An evaluation of mesire places in scope of primary and secondary function change systematics

\begin{tabular}{|c|c|c|c|c|c|c|c|}
\hline \multirow[t]{2}{*}{$\begin{array}{l}\text { Proba- } \\
\text { bility }\end{array}$} & \multirow{2}{*}{$\begin{array}{c}\text { Examples } \\
\text { of } \\
\text { Mesires }\end{array}$} & \multicolumn{2}{|c|}{$\begin{array}{l}\text { Denotation/ } \\
\text { Signifier }\end{array}$} & \multicolumn{2}{|c|}{$\begin{array}{l}\text { Connotation/ } \\
\text { Signified }\end{array}$} & \multicolumn{2}{|c|}{$\begin{array}{c}\text { Codes of } \\
\text { Enrichment }\end{array}$} \\
\hline & & $\mathbf{U}$ & $\mathbf{P}$ & $\mathbf{U}$ & $\mathbf{P}$ & PF & SF \\
\hline
\end{tabular}

2

3

4

Beylerbeyi
Palace
Mesire
Place

5

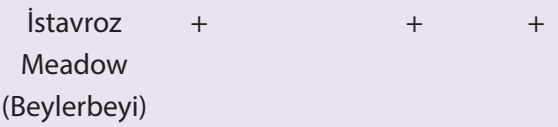

6

Ihlamur
Mesire

(Beylerbeyi)

\section{Remark/Cause}

The fact that this mesire place no longer hosts routines that can assume the duty of recalling events that can create collective memory like meeting recreational demands and allow grazing for imperial horses; it could be said that Uzunçayır mesire is an example of mesire places that has lost its primary and secondary functions.

Today, the mentioned mesire place is used for worshiping rather than recreational purposes. Therefore Yuşa Hill could be regarded as an example of mesires that have lost their primary function but maintain their secondary function.

Ihlamur mesire is now used for recreational purposes. Previously this place was allocated for the private use of the sultan but today it is open to the public. Therefore it could be regarded as an example of mesires that maintains its primary function but lost its secondary function.

The mentioned area is no longer used for recreational purposes nor does it exist as an urban space owned by the sultan in urban memory. Providing touristic services this place has undergone codes of enrichment as put forth by Eco in his example of the pyramid. In this case it could be said that this location has somewhat maintained its property as an element of cultural heritage.

The meadow is no longer used for recreational purposes, the primary function. It could also be said that it has lost its secondary function which refers to social structure that is knows as the Istavroz Meadow in urban memory. A part of the mentioned area has been allocated for military use, so it could be said it is partially preserved even though it is used for different purposes after having undergone codes of enrichment in its primary function.

An example of a completely preserved mesire does not exist. 
bul stand out as significant elements of physical space that exist in the social memory of the Ottoman capital which contribute to social togetherness. As expressed previously an example to this would be different groups using mesire places together and interact with other stakeholders in society at these places.

Examining the original function of mesire places it appears that the concept of recreation comes into prominence. In other words, mesire places are green spaces that address several functions including sports, entertainment and accommodation. In terms of location/position mesires are places inside the city with high accessibility and intense use.

It is possible to mention of several factors that explain the changes taking place in mesire places. Firstly, separate spatial equivalents have been created within the city for each of the functions that formerly took place in mesire places (For example while mesires hosted performances like theatre; today there are separate, specifically equipped facilities for performing arts like theatre, opera and ballet. Examples of similar changes could be given for green space and parks, sports fields, playgrounds, temporary accommodation, singing and dancing activities). In other words, the primary functions of mesires have transformed structurally and been scattered across different parts of urban space.

A second change that could be mentioned is related to the positioning of mesires within the city. It is observed that, today, spaces for specific functions are positioned on the boundaries of the city. This is mainly because of appreciation of land inside the city bringing with it pressure to build.

Another dimension of change could be interpreted over the dimension of organisation. Initially, mesires hosted events/activities organised on the public's own accord; in the $16^{\text {th }}$ century they were administered by the chief imperial gardener and controlled by local governments during the $19^{\text {th }}$ century. Today mesires are subject to the planning authority of the central government.

Evaluating the extent of change expressed about mesires in scope of Eco's primary and secondary function systematics, the primary function or denotation/ signifier is recreation. Whereas the secondary function or connotation/signified could be interpreted as periodical uses carried out in these places which register in urban memory (jewellers using specific mesire places during specific times, grazing imperial horses), abstract meanings ascribed to mesires (those visited based on the public belief that tombs and healing waters exist) and privately used mesires pointing out to the political and social structure of the period (Table 1 ).

Ultimately, the majority of mesires in Istanbul have been lost to development. Parallel to this, the absence of such areas dedicated to public use is being felt more strongly and has come to leave a mark on our daily lives in the form of certain pathological expressions within the city. For instance, using green strips along highways for recreational activities and the increased use of filled land along the coastline for sportive activities and strolling are each examples at attempts to satisfy this need spontaneously or institutionally.

Undoubtedly there are consequences to this change that could be interpreted from a semantic perspective. Mesire places are elements of physical space that constitute an important place in strengthening social ties during the Ottoman period. Of course, there are different forms and solutions to meet this demand in modern Turkey. Change is inevitable in social living conditions and they create their own demands and solutions. The entire issue is how healthy the solutions are, how much they overlap with cultural values and our choices regarding what is erased from our social memory.

\section{References}

Aktaş, U. (2011) İstanbul'un 100 Bahçesi, İstanbul, İstanbul Büyükşehir Belediyesi Kültür A.Ş. Yayınları.

Assmann, J. (2001) Kültürel Bellek Eski Yüksek Kültürlerde Yazı, Hatılama ve Politik Kimlik, A. Tekin çev., İstanbul, Ayrınt Yayınları.

Carman, J. (2002) Archaeology and Heritage: an Introduction, London, Continuum.

Cerasi, M. M. (2001) Osmanlı Kenti - Osmanlı İmparatorluğu'nda 18. ve 19. Yüzyıllarda Kent Uygarlığı ve Mimarisi, İstanbul, Yapı Kredi Yay.

Eco, U. (1980) "Function and Sign: The Semiotics of Architecture", Signs, Symbols and Architecture, Ed: G. Broadbent, R. Bunt, C. Jencks. Bath, John Wiley \& Son, s. 11-69.

Eldem, S. H. (1977) Türk Bahçeleri, İstanbul, MEB Yayınları.

Evyapan, G. A. (1972) Eski Türk Bahçeleri ve Özellikle Eski İstanbul Bahçeleri, Ankara, O.D.T.Ü. Yayınları.

Gürbüz, E. (2009) "Tarih İçerisinde İstanbul'daki Mesire Olgusu ve Mesire Alanlarının Geçirdikleri Değişiminin Kağıthane Mesiresi Örneği Üzerinden İrdelenmesi", Basılmamış Yüksek Lisans Tezi, İstanbul Teknik Üniversitesi Fen Bilimleri Enstitüsü.

Güvenç, B. (2005) İnsan ve Kültür, 11. basım (1972), İstanbul, Remzi Kitabevi.

Howard, P. (2003) Heritage: Management, Interpretation, Identity, London, Continuum.

Kaya, C. F. (2004) "Arkeolojide Kuram ve Uygulama", Basılmamış Yüksek Lisans Tezi, T.C. İstanbul Üniversitesi Sosyal Bilimler Enstitüsü Arkeoloji Anabilim Dalı. 
Mason, R. (2002) "Assessing Values in Conservation Planning: Methodological Issues and Choices", Assessing the Values of Cultural Heritage, Ed: M. D. L. Tore, Los Angeles, The Getty Conservation Institute, pp. 5-30.

Preucel, W. R. and Meskell, L. (2004) "Knowledges", Companion to Social Archaeology, Ed: L. Meskell ve R. W. Preucel, London, Blackwell Publishing, pp. 3-22.

Seçilmişler, T., Özügül, M. D., Yerliyurt, B. (2014) “istanbul’daki Mesire Alanlarında Özgün Kullanım ve Erişilebilirliğinin Değişimi", MiMARisT, 2014/1, ss. 92-98.

\section{Internet References}

Türk Dil Kurumu.http://www.tdk.gov.tr/index. php?option=com_bts\&arama=kelime \&guid=TTD. GTS.545885f2a1c5e9.54526917 [Erişim Tarihi: 03.04.2014].

Key words: Semiology; Istanbul; dennotative and connotative change; Mesire.

Anahtar sözcükler: Anlambilim; istanbul; kullanım ve anlam değeri değişimi; mesire. 